\title{
Simulasi Perkiraan Keuntungan Penjualan Pulsa Dengan menggunakan Metode Monthe Carlo
}

\author{
Fitra Alami Ndruru, Muhammad Daharia, Saiful Nur Arief \\ Sistem Informasi, STMIK Triguna Dharma
}

\begin{tabular}{l}
\hline Article Info \\
\hline Article history: \\
Received Jun $12^{\text {th }}, 2020$ \\
Revised Aug $20^{\text {th }}, 2020$ \\
Accepted Aug $26^{\text {th }}, 2020$ \\
\\
Keyword: \\
Simulasi, Simulasi, Monthe \\
carlo, berbasis web
\end{tabular}

Article Info

icle history:

Revised Aug 20 ${ }^{\text {th }}, 2020$

\begin{abstract}
Bisnis pulsa dikenal masyarakat sebagai kebutuhan penting yang sangat di butuhkan pada era zaman sekarang terlebih untuk setiap orang yang telah mengenal teknologi yang makin berkembang. Dengan adanya Simulasi Perkiraan Keuntungan Penjualan Pulsa dengan menggunakan Metode Monthe Carlo Berbasis Web dapat mempermudah SMA Shop Cell dalam memperkirakan keuntungan penjualan pulsa.
\end{abstract}

Hasil dari penelitian ini sebuah aplikasi berbasis web yang mengimplementasikan Metode Monthe Carlo untuk menghasilkan perkiraan keuntungan penjualan .

\author{
First Author \\ Nama : Fitra alami Ndurur \\ Program Studi : Sistem Informasi \\ STMIK Triguna Dharma \\ Email: fitriaalami@gmail.com
}

\section{PENDAHULUAN}

Indonesia adalah negara besar yang ditandai dengan jumlah penduduk yang besar dan wilayah yang cukup luas, hal ini sangat baik bagi kita selaku orang-orang yang berjiwa bisnis. Ditambah lagi Indonesia juga termasuk negara konsumen, dengan bermodalkan tinggal di negara besar dengan masyarakat yang bersifat konsumtif kita semua dapat dengan relatif mudah mengembangkan bisnis retail [1]. Salah satu bisnis retail yang populer adalah pendistribusian voucher isi ulang pulsa. [2]Semakin banyaknya pengguna telepon genggam membuat kebutuhan akan pulsa semakin meningkat, bahkan saat ini pulsa tidak terbatas lagi hanya untuk penggunaan menelepon dan sms namun juga untuk pembelian paket data Untuk memprediksi tingkat keuntungannya maka diperlukan teknik simulasi salah satunya adalah metode Monthe Carlo yang menguraikan pendapatan keuntungan maka peneliti akan mengembangkan penerapan simulasi perkiraan keuntungan penjualan pulsa dengan metode Monthe Carlo Berbasis Web yang dapat memecahkan masalah pada perkiraan finansial Simulasi Monte Carlo dan dilakukan Berbasis Web yang akan memudahkan pihak perusahaan dalam melakukan pemeriksaan atau pengecekan terhadap keuntungan usaha dimana dan kapan pun.

\section{KAJIAN PUSTAKA}

\subsection{Simulasi Monthe Carlo}

Simulasi Monte Carlo didefinisikan sebagai semua teknik sampling statistik yang digunakan untuk memperkirakan solusi terhadap masalah-masalah kuantitatif. Metode Monte Carlo mengsimulasikan sistem tersebut berulang-ulang kal, ratusan bahkan sampai ribuan kali tergantung sistem yang ditinjau dengan cara memilih sebuah nilai random untuk setiap variabel dari distribusi probabilitasnya [3]

\subsection{Pengertian Simulasi Monthe Carlo}

Menurut Djati metode Monthe Carlo merupakan metode analisis nnumberik yang melibatkan pengambilan sample eksperimen bilangan acak, sedangkan menurut Arifin Monthe Carlo adalah simulasi tipe probabilitas yang mendekati solusi sebuah masalah dengaan melakukan sampling dari proses acak. Simulasi Monte Carlo merupakan simulasi probabilistik dimana suatusolusi dari suatu masalah diberikan berdasarkan proses randomisasi. 


\subsubsection{Metode Monthe Carlo}

Metode Monthe Carlo adalah algoritma komputasi untuk mensimulasikan setiap perilaku pada sistemsecara fisika maupun matematika. Metode ini digunakan untuk mengevaluasikan integral defenit dengan syarat dan batasan yang rumit [4].

\subsection{Unified Modeling Language (UML)}

Unified Modeling Language (UML) adalah bahasa spesifikasi standar yang dipergunakan untuk mendokumentasikan, menspesifikasikan dan membanngun perangkat lunak. UML merupakan metodologi dalam mengembangkan sistem berorientasi objek dan juga merupakan alat untuk mendukung pengembangan sistem [5] Pembangunan utama UML adalah diagram

\section{METODOLOGI PENELITIAN}

\subsection{Metode Penelitian}

Makna Metodologi dalam Penelitian yang bertujuan untuk mengingatkan untuk para peneliti akan pentingnya penggunaan metode sebagai alat untuk menghadapi fenomena dan mencari kebenaran pengetahuan. Didalam metode penelitian ini terdapat beberapa langkah yaitu Data Collecting atau pengumpulan data, dan study of literatur atau studi kepustakaan. Berikut metode peneliti yang digunakan dalam penelitian ini adalah :

1. Teknik Pengumpulan Data (Data Collecting)

Adapun beberapa teknik yang digunakan dalam pengumpulan data dari penelitian yaitu :

a. Pengamatan (Observasi)

Observasi merupakan teknik pengumpulan data yang dilakukan dengan cara melakukan tinjauan langsung ke tempat study kasus dimana akan dilakukan penelitian.

Tabel 3.1 Data primer dari SMA Shop Cell

\begin{tabular}{|c|c|c|c|c|c|c|}
\hline \multirow[b]{2}{*}{ No } & \multirow[b]{2}{*}{ Jenis Pulsa } & \multicolumn{4}{|c|}{ Jumlah penjualan bulan November 2019} & \multirow[b]{2}{*}{ Total } \\
\hline & & $\begin{array}{c}\text { Minggu } \\
\text { ke-1 }\end{array}$ & $\begin{array}{c}\text { Minggu } \\
\text { ke-2 }\end{array}$ & $\begin{array}{c}\text { Minggu } \\
\text { ke-3 }\end{array}$ & $\begin{array}{c}\text { Minggu ke- } \\
4\end{array}$ & \\
\hline 1 & Telkomsel & 50 & 40 & 60 & 30 & 180 \\
\hline 2 & Indosat & 40 & 60 & 30 & 20 & 150 \\
\hline 3 & $\mathrm{XL}$ & 25 & 55 & 50 & 30 & 160 \\
\hline 4 & Axis & 60 & 40 & 60 & 40 & 200 \\
\hline 5 & Tri & 50 & 30 & 40 & 35 & 155 \\
\hline 6 & Esia & 40 & 45 & 35 & 50 & 170 \\
\hline 7 & Fleksi & 40 & 20 & 40 & 20 & 120 \\
\hline
\end{tabular}

Table 3.2 Daftar harga jual keseluruhan berdasarkan jenis pulsa

\begin{tabular}{|l|l|l|}
\hline No & \multicolumn{1}{|c|}{ Jenis Pulsa } & \multicolumn{1}{c|}{ Harga jual } \\
\hline 1 & Telkomsel & Rp 1.732 .000 \\
\hline 2 & Indosat & $\mathrm{Rp} 1.300 .000$ \\
\hline 3 & XL & $\mathrm{Rp} 2.520 .000$ \\
\hline 4 & Axis & $\mathrm{Rp} 3.300 .000$ \\
\hline 5 & Tri & $\mathrm{Rp} 1.200 .000$ \\
\hline 6 & Esia & $\mathrm{Rp} 1.000 .000$ \\
\hline 7 & Fleksi & $\mathrm{Rp} 500.000$ \\
\hline
\end{tabular}

Dari data perjualan tersebut maka akan menjadi penentu dalam simulasi perkiraan penjualan pulsa. Dengan langkah-langkah yang digunakan :

Tabel 3.3 Langkah-langkah penyelesaian

\begin{tabular}{|l|l|}
\hline No & \multicolumn{1}{|c|}{ Keterangan } \\
\hline 1 & Menentukan distibusi probabilitas dan distribusi probabilitas kumulatif \\
\hline 2 & Menentukan interval acak \\
\hline 3 & Melakukan percobaan \\
\hline 4 & Tentukan hasil perkiraan \\
\hline
\end{tabular}


1. Studi Kepustakaan (Library Search)

Dalam studi literatur banyak menggunakan jurnal baik dari jurnal internasional, jurnal nasional, jurnal lokal maupun buku referensi lainnya yang berkaitan dengan penelitian sebagai referensi, studi pustaka merupakan metode pengumpulan data yang diarahkan kepada pencarian data dan informasi melalui dokumen-dokumen, baik dokumen tertulis, foto-foto, gambar, maupun dokumen elektronik yang dapat mendukung dalam proses penulisan.

\subsection{Metode Perancangan Sistem}

Unsur yang penting dalam penelitian adalah metode perancangan sistem, khususnya dalam perancangan sistem yang menggunakan software atau perangkat lunak, perangkat lunak menggambarkan aktivitas pengembangan dalam sistem.

3.3 Algoritma Sistem

Algoritma sistem merupakan penjelasan langkah-langkah dalam menyelesaikan masalah

1. Flowchart Algoritma Dari Metode Monthe Carlo

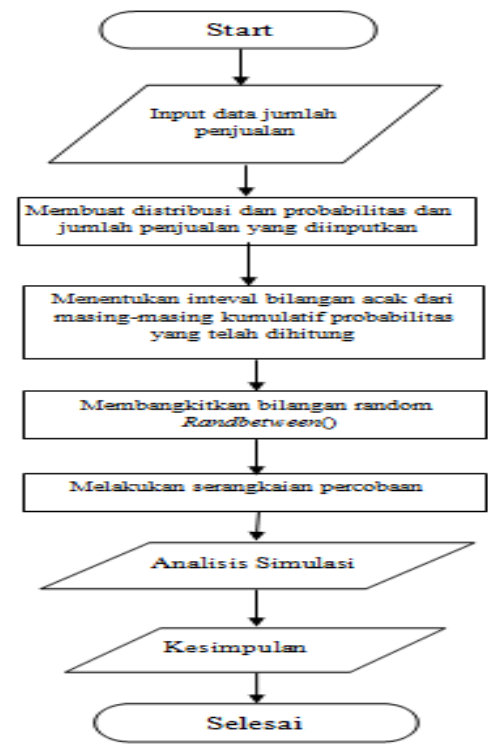

Gambar 3.1 Flowchart penyelesaian metode Monthe Carlo

2. Penyelesaian dengan Metode Monthe Carlo

Dibawah ini adalah tahapan perhitungan dengan metode Monthe Carlo:

a. Menentukan distibusi probabilitas dan distribusi probabilitas kumulatif

Tabel 3.5 Probabilitas dan Probabilitas Kumulatif

\begin{tabular}{|l|l|l|l|}
\hline \multirow{2}{*}{ No } & \multicolumn{3}{|l|}{ Jumlah penjualan bulan November 2019 } \\
\cline { 2 - 4 } & Telkomsel & \multicolumn{1}{|c|}{ Probabilitas } & Probabilitas Kumulatif \\
\hline 1 & $50 / 180$ & 0.28 & 0.28 \\
\hline 2 & $40 / 180$ & 0.22 & 0.50 \\
\hline 3 & $60 / 180$ & 0.33 & 0.83 \\
\hline 4 & $30 / 180$ & 0.17 & 1.00 \\
\hline
\end{tabular}


Tabel 3.5 Probabilitas dan Probabilitas Kumulatif (Lanjutan)

\begin{tabular}{|l|l|l|l|}
\hline \multirow{2}{*}{ No } & \multicolumn{3}{|l|}{ Jumlah penjualan bulan November 2019 } \\
\cline { 2 - 4 } & \multicolumn{1}{|c|}{ Indosat } & \multicolumn{1}{|l|}{ Probabilitas } & Probabilitas Kumulatif \\
\hline 5 & $40 / 150$ & 0.22 & 0.22 \\
\hline 6 & $60 / 150$ & 0.33 & 0.55 \\
\hline 7 & $30 / 150$ & 0.17 & 0.72 \\
\hline 8 & $20 / 150$ & 0.11 & 0.83 \\
\hline
\end{tabular}

Tabel 3.5 Probabilitas dan Probabilitas Kumulatif (Lanjutan)

\begin{tabular}{|c|c|c|c|}
\hline \multirow[b]{2}{*}{ No } & \multicolumn{3}{|c|}{ Jumlah penjualan bulan November 2019} \\
\hline & XL & Probabilitas & $\begin{array}{c}\text { Prob. } \\
\text { Kumulatif }\end{array}$ \\
\hline 9 & $25 / 160$ & 0.16 & 0.16 \\
\hline 10 & $55 / 160$ & 0.34 & 0.50 \\
\hline 11 & $50 / 160$ & 0.31 & 0.81 \\
\hline 12 & $30 / 160$ & 0.19 & 1.00 \\
\hline
\end{tabular}

Tabel 3.5 Probabilitas dan Probabilitas Kumulatif (Lanjutan)

\begin{tabular}{|c|c|c|c|}
\hline \multirow[b]{2}{*}{ No } & \multicolumn{3}{|c|}{ Jumlah penjualan bulan November 2019} \\
\hline & Axis & Probabilitas & $\begin{array}{c}\text { Prob. } \\
\text { Kumulatif }\end{array}$ \\
\hline 13 & $60 / 200$ & 0.3 & 0.3 \\
\hline 14 & $40 / 200$ & 0.2 & 0.5 \\
\hline 15 & $60 / 200$ & 0.3 & 0.8 \\
\hline 16 & $40 / 200$ & 0.2 & 1.0 \\
\hline
\end{tabular}

Tabel 3.5 Probabilitas dan Probabilitas Kumulatif (Lanjutan)

\begin{tabular}{|l|l|r|l|}
\hline \multirow{2}{*}{ No } & \multicolumn{4}{|l|}{ Jumlah penjualan bulan November 2019} \\
\cline { 2 - 4 } & \multicolumn{1}{|c|}{ Tri } & \multicolumn{1}{|l|}{ Probabilitas } & Probabilitas Kumulatif \\
\hline 17 & $50 / 155$ & 0.32 & 0.32 \\
\hline 18 & $30 / 155$ & 0.19 & 0.51 \\
\hline 19 & $40 / 155$ & 0.26 & 0.77 \\
\hline 20 & $35 / 155$ & 0.23 & 1.00 \\
\hline
\end{tabular}

Tabel 3.5 Probabilitas dan Probabilitas Kumulatif (Lanjutan)

\begin{tabular}{|c|c|c|c|}
\hline \multirow{2}{*}{ No } & \multicolumn{3}{|c|}{ Jumlah penjualan bulan November 2019} \\
\hline & Esia & Probabilitas & Probabilitas Kumulatif \\
\hline 21 & $40 / 170$ & 0.24 & 0.24 \\
\hline 22 & $45 / 170$ & 0.26 & 0.50 \\
\hline 23 & $35 / 170$ & 0.21 & 0.71 \\
\hline 24 & $50 / 170$ & 0.29 & 1.00 \\
\hline
\end{tabular}

Tabel 3.5 Probabilitas dan Probabilitas Kumulatif (Lanjutan) 


\begin{tabular}{|c|c|c|c|}
\hline \multirow{2}{*}{ No } & \multicolumn{3}{|c|}{ Jumlah penjualan bulan November 2019} \\
\hline & Fleksi & Probabilitas & Probabilitas Kumulatif \\
\hline 25 & $40 / 120$ & 0.33 & 0.33 \\
\hline 26 & $20 / 120$ & 0.17 & 0.50 \\
\hline 27 & $40 / 120$ & 0.33 & 0.83 \\
\hline 28 & $20 / 120$ & 0.17 & 1.00 \\
\hline
\end{tabular}

b. Menentukan Interval Acak

Tabel 3.6 Interval bilangan acak dari probabilitas kumulatif

\begin{tabular}{|l|r|l|l|}
\hline \multirow{2}{*}{ No } & \multicolumn{3}{|c|}{ Jenis Pulsa Telkomsel } \\
\cline { 2 - 4 } & Probabilitas & Probabilitas Kumulatif & \multicolumn{1}{c|}{ Interval Bilangan acak } \\
\hline 1 & 0.28 & 0.28 & $0-27$ \\
\hline 2 & 0.22 & 0.50 & $28-49$ \\
\hline 3 & 0.33 & 0.83 & $50-82$ \\
\hline 4 & 0.17 & 1.00 & $83-100$ \\
\hline
\end{tabular}

Tabel 3.6 Interval bilangan acak dari probabilitas kumulatif(lanjutan)

\begin{tabular}{|l|l|l|l|}
\hline \multirow{2}{*}{ No } & \multicolumn{3}{|c|}{ Jenis Pulsa Indosat } \\
\cline { 2 - 4 } & \multicolumn{1}{|c|}{ Probabilitas } & Probabilitas Kumulatif & Interval Bilangan acak \\
\hline 5 & 0.22 & 0.22 & $0-21$ \\
\hline 6 & 0.33 & 0.55 & $22-54$ \\
\hline 7 & 0.17 & 0.72 & $55-72$ \\
\hline 8 & 0.11 & 0.83 & $72-100$ \\
\hline
\end{tabular}

Tabel 3.6 Interval bilangan acak dari probabilitas kumulatif(lanjutan)

\begin{tabular}{|l|l|l|l|}
\hline \multirow{2}{*}{ No } & \multicolumn{3}{|c|}{ Jenis Pulsa XL } \\
\cline { 2 - 4 } & \multicolumn{1}{|c|}{ Probabilitas } & Probabilitas Kumulatif & Interval Bilangan acak \\
\hline 5 & 0.22 & 0.22 & $0-21$ \\
\hline 6 & 0.33 & 0.55 & $22-54$ \\
\hline 7 & 0.17 & 0.72 & $55-72$ \\
\hline 8 & 0.11 & 0.83 & $72-100$ \\
\hline
\end{tabular}

Tabel 3.6 Interval bilangan acak dari probabilitas kumulatif(lanjutan)

\begin{tabular}{|l|l|l|l|}
\hline \multirow{2}{*}{ No } & \multicolumn{3}{|c|}{ Jenis Pulsa Axis } \\
\cline { 2 - 4 } & Probabilitas & Probabilitas Kumulatif & Interval Bilangan acak \\
\hline 13 & 0.3 & 0.3 & $0-2$ \\
\hline 14 & 0.2 & 0.5 & $3-4$ \\
\hline 15 & 0.3 & 0.8 & $5-7$ \\
\hline 16 & 0.2 & 1.0 & $8-10$ \\
\hline
\end{tabular}

Tabel 3.6 Interval bilangan acak dari probabilitas kumulatif(lanjutan) 


\begin{tabular}{|c|c|c|c|}
\hline \multirow{2}{*}{ No } & \multicolumn{3}{|c|}{ Jenis Pulsa Tri } \\
\hline & Probabilitas & Probabilitas Kumulatif & Interval Bilangan acak \\
\hline 17 & 0.32 & 0.32 & $0-31$ \\
\hline 18 & 0.19 & 0.51 & $32-50$ \\
\hline 19 & 0.26 & 0.77 & $51-76$ \\
\hline 20 & 0.23 & 1.00 & $77-100$ \\
\hline
\end{tabular}

Tabel 3.6 Interval bilangan acak dari probabilitas kumulatif(lanjutan)

\begin{tabular}{|l|l|l|l|}
\hline \multirow{2}{*}{ No } & \multicolumn{3}{|c|}{ Jenis Pulsa Esia } \\
\cline { 2 - 4 } & \multicolumn{1}{|c|}{ Probabilitas } & Probabilitas Kumulatif & \multicolumn{1}{c|}{ Interval Bilangan acak } \\
\hline 21 & 0.24 & 0.24 & $0-23$ \\
\hline 22 & 0.26 & 0.50 & $24-49$ \\
\hline 23 & 0.21 & 0.71 & $50-70$ \\
\hline 24 & 0.29 & 1.00 & $71-100$ \\
\hline
\end{tabular}

Tabel 3.6 Interval bilangan acak dari probabilitas kumulatif(lanjutan)

\begin{tabular}{|l|l|l|l|}
\hline \multirow{2}{*}{ No } & \multicolumn{3}{|c|}{ Jenis Pulsa Fleksi } \\
\cline { 2 - 4 } & \multicolumn{1}{|c|}{ Probabilitas } & Probabilitas Kumulatif & \multicolumn{1}{c|}{ Interval Bilangan acak } \\
\hline 25 & 0.33 & 0.33 & $0-32$ \\
\hline 26 & 0.17 & 0.50 & $33-49$ \\
\hline 27 & 0.33 & 0.83 & $50-82$ \\
\hline 28 & 0.17 & 1.00 & $83-100$ \\
\hline
\end{tabular}

c. Membentuk bilangan acak

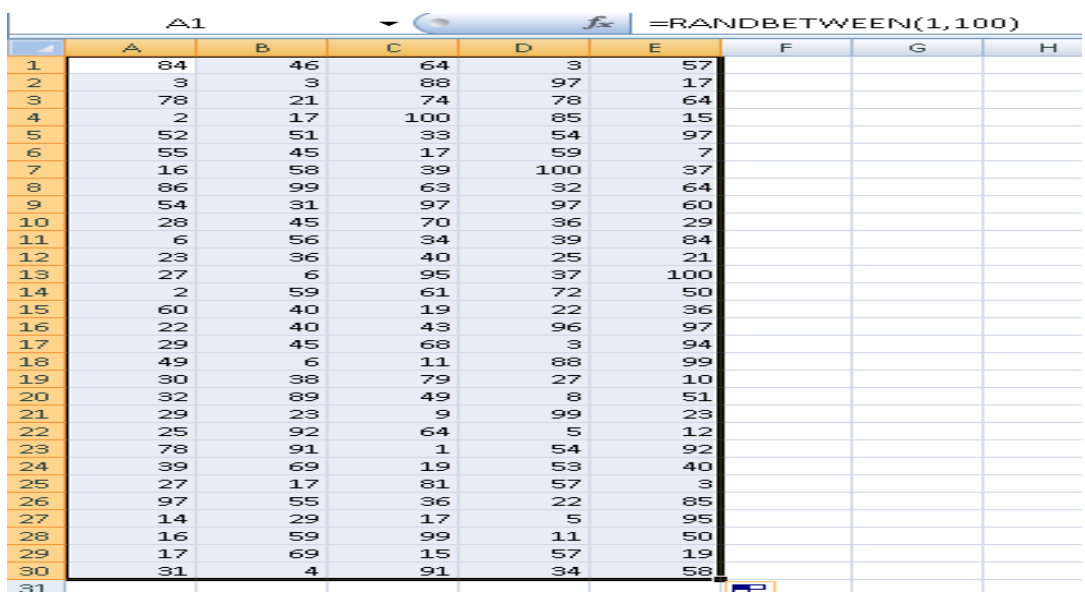

Gambar 3.2 Bilangan acak 
d. Membuat simulasi dari rangkaian percobaan

Tabel 3.7 Jumlah penjualan (Simulasi)

\begin{tabular}{|c|c|c|c|c|c|c|c|c|}
\hline \multirow[t]{2}{*}{ Hari } & \multirow{2}{*}{$\begin{array}{l}\text { Angka } \\
\text { acak }\end{array}$} & \multicolumn{7}{|c|}{ Jumlah penjualan simulasi } \\
\hline & & Telkomsel & Indosat & $\mathrm{XL}$ & Axi & $\operatorname{Tri}$ & Esia & Fleksi \\
\hline 1 & 84 & 30 & 20 & 30 & 40 & 35 & 50 & 20 \\
\hline 2 & 3 & 50 & 40 & 25 & 40 & 50 & 40 & 40 \\
\hline 3 & 78 & 60 & 20 & 50 & 60 & 35 & 50 & 40 \\
\hline 4 & 2 & 50 & 40 & 25 & 60 & 50 & 40 & 40 \\
\hline 5 & 52 & 60 & 60 & 50 & 60 & 40 & 35 & 40 \\
\hline & otal & 250 & 180 & 180 & 320 & 210 & 215 & 140 \\
\hline
\end{tabular}

1. Rata rata permintaan pulsa telkomsel per Minggu : $250 / 5=50$

Cara ekspektasi:

$\mathrm{E}=\sum_{\mathrm{i}=0}^{4}$ (Probabilitas dari pulsa) $x$ (permintaan pulsa)

$(0.28(50)+0.22(40)+0.33(60)+0.17(30)=47.4$ atau $47 / \mathrm{minggu}$

2. Rata rata permintaan pulsa Indosat perminggu : $180 / 5=36$

Cara ekspetasi :

$\mathrm{E}=\sum_{\mathrm{i}=0}^{4}$ (Probabilitas dari pulsa) $x$ (permintaan pulsa)

$0.22(40)+0.33(60)+0.17(30)+0.11(420)=35.9$ atau $36 / \mathrm{minggu}$

3. Rata rata permintaan pulsa XL per hari : $180 / 5=36$

Cara ekspektasi:

$\mathrm{E}=\sum_{\mathrm{i}=0}^{4}$ (Probabilitas dari pulsa) $x$ (permintaan pulsa)

$0.16(25)+0.34(55)+0.31(50)+0.19(30)=43.9$ atau 44/minggu

4. Rata rata permintaan pulsa Axis per hari : $320 / 5=64$

Cara ekspektasi:

$\mathrm{E}=\sum_{\mathrm{i}=0}^{4}$ (Probabilitas dari pulsa) $x$ (permintaan pulsa)

$0.3(60)+0.2(40)+0.3(60)+0.3(40)=50 /$ minggu

5. Rata rata permintaan pulsa Tri per hari : $210 / 5=42$

Cara ekspektasi:

$\mathrm{E}=\sum_{\mathrm{i}=0}^{4}$ (Probabilitas dari pulsa) $x$ (permintaan pulsa)

$0.32(50)+0.19(30)+0.26(40)+0.23(35)=40.15$ atau $40 / \mathrm{minggu}$

6. Rata rata permintaan pulsa Esia per hari : $215 / 5=43$

Cara ekspektasi:

$\mathrm{E}=\sum_{\mathrm{i}=0}^{4}$ (Probabilitas dari pulsa) $x$ (permintaan pulsa)

$0.24(40)+0.26(45)+0.21(35)+0.29(50)=43.15$ atau $43 / \mathrm{minggu}$

7. Rata rata permintaan pulsa Fleksi per minggu : $140 / 5=28$

Cara ekspektasi:

$\mathrm{E}=\sum_{\mathrm{i}=0}^{4}($ Probabilitas dari pulsa) $x$ (permintaan pulsa)

$0.33(40)+0.17(20)+0.33(40)+0.17(20)=33.2$ atau 33/minggu

Untuk mencari perkiraan keuntungan penjualan (Simulasi) dapat dilakukan dengan :

\section{Harga jual keseluruhan jenis pulsa total penjualan jenis pulsa $X$ jumlah permintaan}

Dik : Telkomsel harga jual keseluruhan Rp.1.732.000 dan total keseluruhan penjualan sebanyak 180 maka : $=\underline{1.732 .000} \times 50$

180

$=9.6 \times 50=480$ 
Hasil keseluruhannya dapat dilihat pada tabel dibawah ini :

Tabel 3.8 perkiraan keuntungan penjualan pulsa (Simulasi)/bulan

\begin{tabular}{|l|l|l|l|}
\hline No & \multicolumn{1}{|c|}{ Jenis Pulsa } & $\begin{array}{c}\text { Jumlah } \\
\text { permintaan }\end{array}$ & \multicolumn{1}{c|}{ Keuntungan } \\
\hline 1 & Telkomsel & 50 & Rp. 481.000 .00 \\
\hline 2 & Indosat & 36 & Rp. 312.012 .00 \\
\hline 3 & XL & 36 & Rp. 567.000 .00 \\
\hline 4 & Axis & 64 & Rp. 1.056 .000 .00 \\
\hline 5 & Tri & 42 & Rp. 312.564 .00 \\
\hline 6 & Esia & 43 & Rp. 252.962.00 \\
\hline 7 & Fleksi & 28 & Rp. 116.676 .00 \\
\hline $\begin{array}{l}\text { Total permintaan dan } \\
\text { keuntungan }\end{array}$ & 299 & Rp. .3.121.650.00 \\
\hline
\end{tabular}

Dari tabel diatas Total keuntungan/bulan sebesar Rp. 3.121.650.00

\section{Hasil}

Implementasi merupakan langkah yang digunakan untuk mengoperasikan sistem yang akan dibangun. Dalam bab ini akan dijelaskan bagaimana menjalankan sistem yang telah dibangun tersebut. Implementasi sebagai dukungan sistem analisa diperlukan beberapa perangkat-perangkat sebagai berikut:

1. Tampilan Form Menu Utama

Berikut ini merupakan tampilan dari form menu utama yang merupakan tampilan yang akan dikunjungin oleh user sebelum login

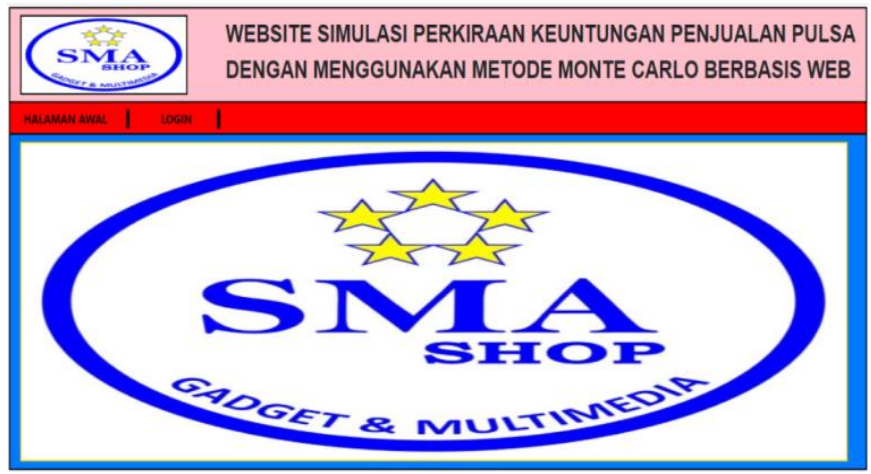

Gambar 4.1 Tampilan Menu Utama

2. Tampilan Form Login

Berikut ini merupakan Form Login tampilan dari sistem yang telah dibangun.

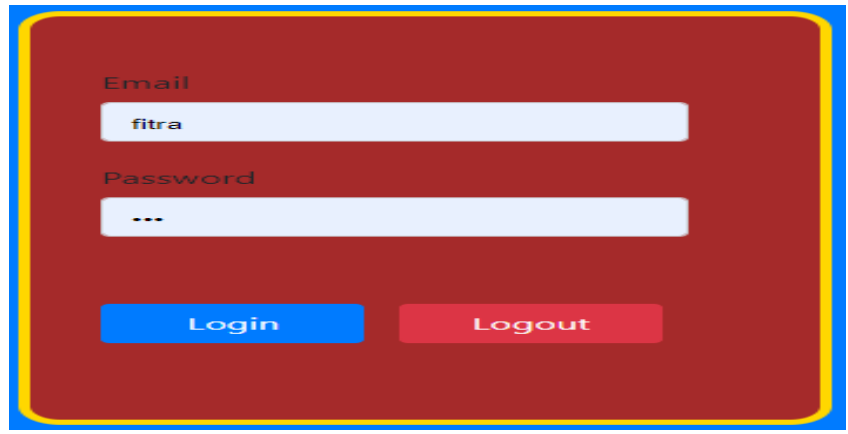

Gambar 4.2 Tampilan Form Login 
3. Tampilan Form Menu Utama Pengolahan Data Pulsa

Berikut ini adalah tampilan form menu utama pengolahan data pulsa

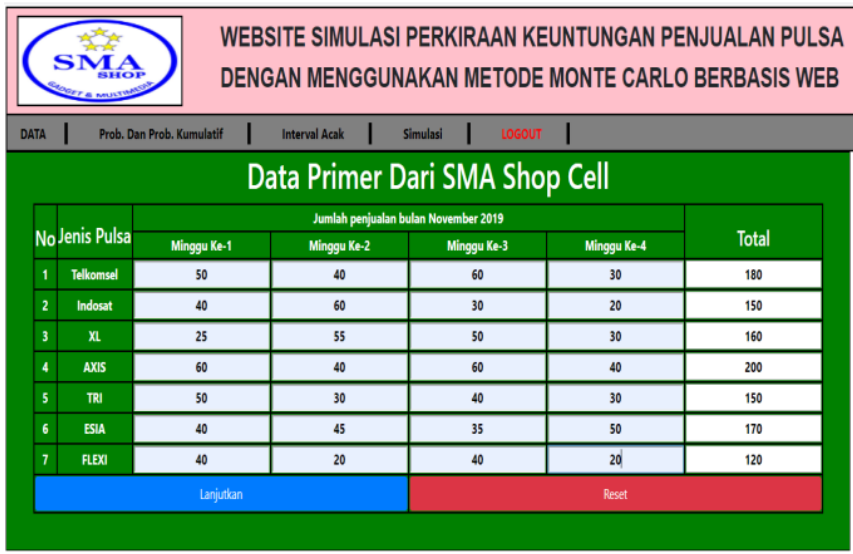

Gambar 4.3 Tampilan Form Data Penjualan

4. Tampilan Form Probabilitas dan Probabilitas Kumulatif

Berikut ini adalah Tampilan form Probabilitas dan Probabilitas Kumulatif yaitu:

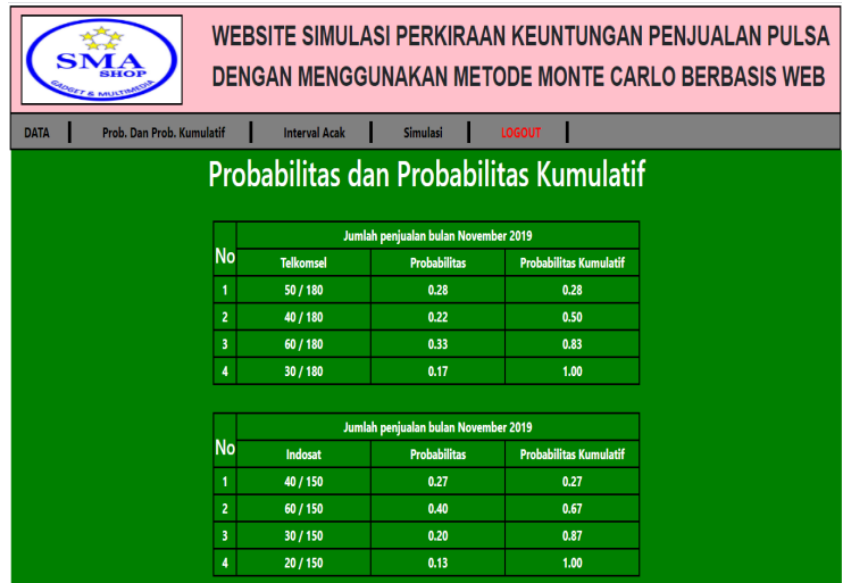

Gambar 4.4 Tampilan Form Probabilitas dan Probabilitas Kumulatif

5. Tampilan Form Interval Acak

Berikut ini adalah tampilan Form Interval Acak yaitu :

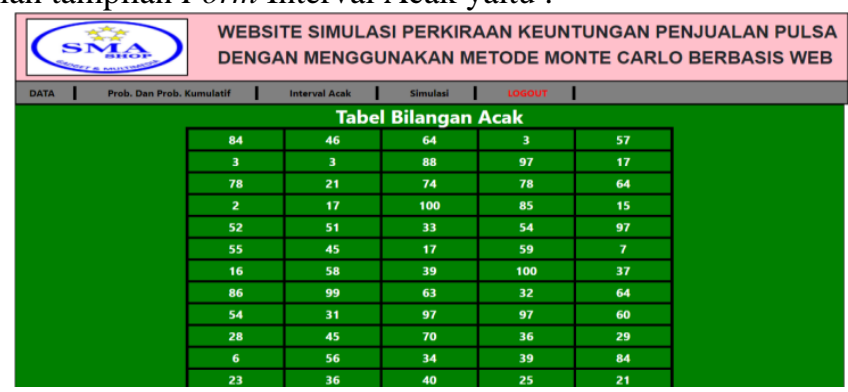

Gambar 4.5 Tampilan Form Interval Acak

6. Tampilan Form Simulasi

Berikut ini adalah Tampilan Form Simulasi : 


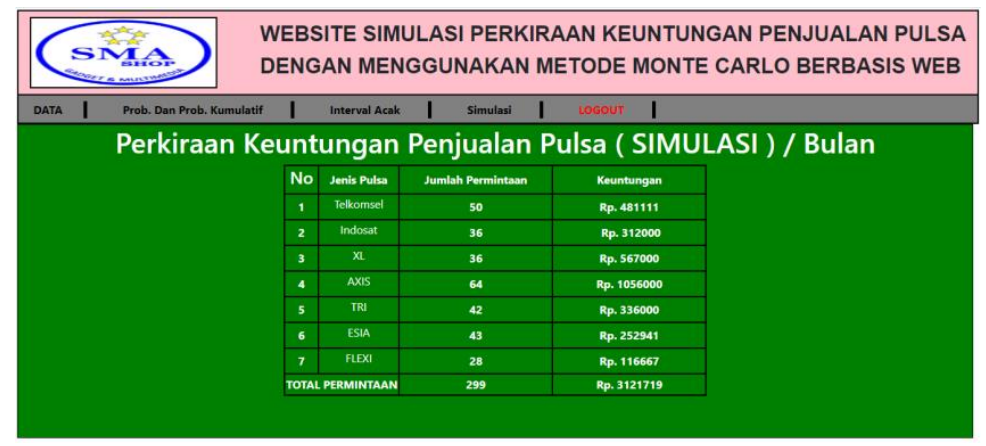

Gambar 4.6 Tampilan Form Simulasi

\section{KESIMPULAN}

Dari hasil pembahasan dari Bab 1 sampai Bab 5 mengenai simulasi perkiraan keuntungan penjualan pulsa dengan menggunakan metode monthe carlo berbasis web dapat diambil kesimpulan adalah sebagai berikut:

1. Berdasarkan pengujian dan implementasi terhadap simulasi perkiraan keuntungan penjualan pulsa dengan menggunakan metode monthe carlo berbasis web maka perkiraan keuntungan dapat dilakukan dengan mudah.

2. Berdasarkan hasil analisa, metode monthe carlo dapat diterapkan dalam pemecahan masalah pada SMA SHOP dalam hal perkiraan keuntungan.

3. Berdasarkan penelitian, dalam upaya memodelkan simulasi dengan metode monthe carlo yang dirancang diawali dengan analisis masalah kebutuhan kemudian dilakukan pemodelan.

4. Dengan menggunakan bahasa pemrograman web dan database Mysq laplikasi simulasi dengan metode monthe carlo dapat dirancang.

5. Aplikasi yang dibagun dapat dijalankan oleh user dengan menggunakan setiap tahapan yang ada mulai dari input data pulsa, mencari probabilitas dan probabilitas kumulatif, interval acak, sampai uji coba,pada proses metode Monthe Carlo.

\section{REFERENSI}

[1] “1,2 1, 2*," vol. 3, no. 2, pp. 111-121, 2018.

[2] Y. E. Praptiningsih, W. W. Ariestya, and N. Mustaufa, "Perancangan Sistem Penjualan Pulsa," vol. VIII, no. 2, 2016.

[3] P. Silindak, D. Menggunakan, M. M. Carlo, I. Pendahuluan, and M. Monte, "Prediksi penjualan barang pada koperasi pt. perkebunan silindak dengan menggunakan metode monte carlo," vol. 3, no. 6, pp. 65-69, 2016.

[4] I. Masalah, "Simulasi Perkiraan Keuntungan Penjualan,” pp. 978-979, 2015.

[5] S. Disa and M. C. Mc, "Sepatu perharinya dengan Metode Monthe Carlo ( Studi Kasus Toko Sepatu PRO SADIRA EDAR ),” pp. 1-5. 